\title{
The Role of Intellectual Capital in Overcoming the Slowing Economic Growth in Indonesia
}

\author{
Mahatma Kufepaksi ${ }^{1} \&$ Gunawan $^{1,}$ \\ ${ }^{1}$ Faculty of Economics and Business, University of Lampung, Bandar Lampung, Indonesia \\ Correspondence: Gunawan, Faculty of Economics and Business, University of Lampung, Bandar Lampung, \\ Indonesia, Indonesia. Tel: 721-701-979. E-mail: gunawan.unila@gmail.com
}

Received: August 29, 2018

Accepted: September 18, $2018 \quad$ Online Published: September 25, 2018

doi:10.5539/ijef.v10n10p97

URL: https://doi.org/10.5539/ijef.v10n10p97

\begin{abstract}
Intellectual capital is one of the important factors that play a major role in various economic activities. However, its position in overcoming economic problems in Indonesia is still not too much considered. Based on this, this study aims to describe the role of intellectual capital, especially the Human Capital dimension, in overcoming the economic slowdown in Indonesia.

The type of this research is qualitative. Research data in the form of secondary data is collected through documentation studies of data related to human capital and Indonesia's economic growth, as well as the results of previous studies that have relevance to the topic of this study. The data is then analyzed using qualitative methods.

The results of this study are: 1) Intellectual capital has a fundamental role in overcoming the economic slowdown in Indonesia. One dimension of intellectual capital, namely human capital, can have a diverse role, both as a factor of production and as an economic policy maker, so that its existence and quality determine the success of the strategy formulation and its implementation to overcome the economic slowdown in Indonesia; and 2) The role of intellectual capital, especially human capital, can be realized if Indonesia changes its development paradigm to become more oriented towards the development of human resources quality.
\end{abstract}

Keywords: intellectual capital, human capital, economic growth

\section{Introduction}

Stable and sustainable economic growth is the goal of every country in the world. However, to be able to achieve these conditions, extra-hard effort which involves various micro and macro factors as well as strong synergy between all economic actors is needed. In addition, increasing economic growth will not be achieved if there are still many underlying problems that have not been resolved and disrupt the economic processes. Moreover, the increasingly strong globalization of the world will also have a negative impact on countries with unstable economies and have many internal problems, such as Indonesia.

Indonesia's economic growth is currently experiencing a slowdown. This can be seen in the percentage rate of growth GDP data, that has fluctuated from year to year below:

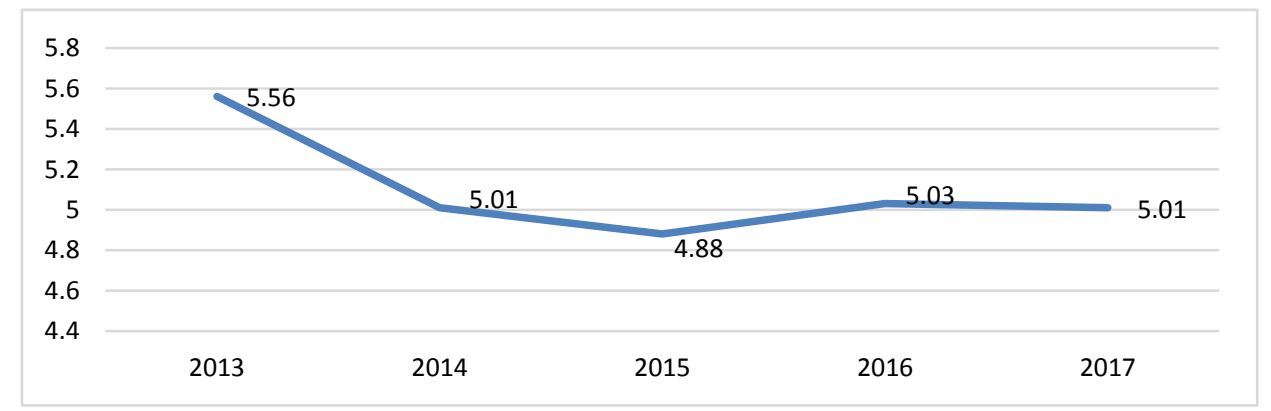

Figure 1. Slowing Indonesian economic growth

Source: Bi.go.id (2017). 
The data above shows that the condition of the Indonesian economy has decreased significantly from 2013 which had a GDP percentage of $5.56 \%$ to $5.01 \%$ in 2014 , then declined again to $4.88 \%$ in 2015 . This value indicates a strengthening with rose to 5.03\% in 2016, but then fell back to $5.01 \%$ in 2017.

The slowdown in Indonesia's economic growth can theoretically be caused by a variety of factors. When referring to classical growth theory, then there are five factors that influence it, namely the factor of human resources, availability of capital goods, natural wealth, and technology. According to Schumpter's theory, the dominant factors affecting economic growth are entrepreneurial factors. Harrod Domar's theory states that economic growth is influenced by the balance between investment, production and demand. According to neo-classical theory, population growth, capital increase, and efficiency of technology use are factors that influence economic growth. When referring to the analysis carried out by the Indonesian Ministry of Finance, Indonesia's economic growth is mainly influenced by four factors, namely: 1) household consumption, social spending, and major events; 2) government consumption; 3) investment; and 4) exports and imports (www.kemenkeu.go.id, 2017).

According to the results of previous studies, economic growth can be influenced by investment, human capital, and education spending (Saepudin, 2013; Ewubare \& Ogbuagu, 2015); consumption level and export value (Kira, 2013); physical capital and foreign investment (Havi, Enu, Osei-Gyimah, Attah-Obeng, \& Opoku, 2013).

There is similarity between the theoretical perspective and the results of previous studies, that the factor of human capital is a factor that always exists and has a role in economic activities that encourage the creation of economic growth. However, this factor is not included in the factors considered to influence economic growth by the Indonesian government.

Human capital (HC) is one dimension of Intellectual capital in addition to other dimensions, namely structural capital and relational capital. In a small scope, namely the level of an organization or company, HC is recognized as the most important capital needed to be able to achieve company goals (Makki \& Lodhi, 2014). This is in line with resource-based theory (RBT) which emphasizes the importance of aspects of internal resources, namely people who are members of a company or organization, as owners of knowledge which are the source of innovation and the creation of superior competitiveness (Wan, Hoskisson, Short, \& Yiu, 2011). In a larger scope, $\mathrm{HC}$ also proved to be a factor that has a major influence on the country's economic growth (Borojo \& Yushi, 2015; Arabi \& Abdalla, 2013; Jihène, 2013).

Based on the overall explanation above, the questions that arise in this study are: how is the role of intellectual capital in overcoming the economic slowdown in Indonesia?. Referring to the research question, the purpose of this study is to describe the role of intellectual capital in overcoming the economic slowdown in Indonesia.

\section{Literature Review}

\subsection{Economic Growth}

Economic growth is one of the main indicators used to measure economic performance and competition in a country. Economic growth is known from an increase in the ability of the state to provide various economic needs for its citizens, in accordance with the adaptation made to the development of technology and its implementation (Jhingan, 2012).

Economic growth is an increase in the empowerment of production factors that produce output in the form of a better level of community welfare in a period of time. Empowerment is carried out through various economic activities in various sectors, whether carried out individually, in groups, or in organizations, which are clearly capable of creating results that are beneficial in encouraging the increment of community income (Maramis, 2013).

The study of economic growth generally refers to four theoretical perspectives, namely Classical Growth Theory; Schumpeter's theory; Harrod-Domar theory; and Neo Classical Growth Theory. Classical growth theory states that economic growth is influenced by five factors, namely the factor of human resources, availability of capital goods, natural wealth, and technology. According to this theory, the factor of human resources, or more specifically the factor of population that continues to increase over time is the most dominant factor affecting economic growth (Masoud, 2014).

Schumpter's theory states that the economy on a macro scale is strongly influenced by entrepreneurial factors, namely how entrepreneurs in an area conduct their economic activities and are motivated to continuously innovate (Croitoru, 2012). According to the theory developed by Harrod Domar, economic growth is strongly influenced by investments that encourage production increament. However, such production must also be carried out by referring the public demand for products to create a long term balance and economic stability (Berg, 
2013).

The neo-classical theory states that economic growth is influenced by factors of production which consist of population growth, capital increase, and efficiency in the use of technology. In practice, this theory emphasizes the importance of policies or regulations related to the right investment system and the use of these investments to improve the efficiency of technological applications (Ewubare \& Ogbuagu, 2015).

\subsection{Resource Based Theory}

Resource-based Theory (RBT) was popularized by Penrose in 1959. This theory appears as a pioneer of reasoning that emphasizes the importance of the contribution of the company's internal resources in creating superior competitiveness and differentiation from other companies. Contributions in this case are based on intellectual elements of internal resources, or rather refer to the knowledge possessed by humans as the most important resources that exist in the company (Wan et al., 2011).

According to RBT, the achievement of a company is based on the contribution of resources and knowledge of the company, which is also as a differentiator from other companies (Olalla, 1999). The strategy applied by an organization can have in common with the strategies of other organizations, because strategy is something that can be replicated. Therefore, to be able to provide advantages over other organizations, the resources and capabilities of the organization must be valuable, rare, cannot be replicated, and cannot be replaced (Theriou, Aggelidis, \& Theriou, 2009).

Based on Resource-based Theory (RBT), two views emerged regarding internal organizational resources, namely Resource-Based View (RBV) and Knowledge-Based View (KBV). The RBV considers that organizational performance is the result of unique or special resources and capabilities of the organization, while Knowledge-Based View (KBV) describes an organization as a unit that creates, integrates and distributes knowledge (Theriou et al., 2009).

\subsection{Intellectual Capital}

Intellectual capital (IC) is a concept that was first introduced in 1991 by Stewart. The concept was then further examined by various researchers to find a fairly representative definition, that IC is an intellectual aspect in the form of knowledge which become the basic capital needed to obtain profits in the future. IC can include ideas, technology, processes, and certain findings (Leaniz \& Bosque, 2013).

Intellectual capital (IC) is defined generally as intangible capital, which is related to human experience and knowledge. In the organizational sphere, intellectual capital is defined as a collection of important assets that shape organizational knowledge and have a dominant influence in encouraging the improvement of organizational competitiveness (Solikhah \& Subowo, 2016). These assets can be in the form of experience, professional skills, good cooperative relationships, knowledge, or applied technology (Li, Pike, \& Haniffa, 2008). Proper management of intellectual capital can also encourage the creation of various values needed to achieve the stated goals and vision (Abdulai \& Kwon, 2012).

As intangible capital, intellectual capital is difficult to observe and measure (Cheng, Lin, Hsiao, \& Lin, 2010). Nevertheless, its existence has been recognized as the main capital in conducting research, development, creating innovation, improving product quality, and improving the quality of human resources (Orens, Aerts, \& Lybaert, 2009). Intellectual capital has three dimensions, namely human capital (HC), relational capital (RC), and structural capital (SC) (Pablos, 2003).

\subsubsection{Human Capital}

Human capital (HC) relates to all aspects of productive endowments inherent in human resources (HR). This capital can be in the form of competence, experience, knowledge, ability, behavior, habits, and commitment possessed by HR (Canizares, Munoz, \& Guzman, 2007). HC is referred to as the most important capital owned by every company, regardless the type or category of the business sector, because $\mathrm{HC}$ is proven to be the main factor that drives efficiency increment of various activities carried out, as well as being the creator of all intangible assets in the company (Makki \& Lodhi, 2014).

The position of $\mathrm{HC}$ which is so important in the company has a fundamental weakness, that is if the qualified human resources are no longer a member of the company, then $\mathrm{HC}$ will also be lost. Therefore, management of $\mathrm{HR}$ is very important to be able to make HC stays longer according to the needs of the company, and allows transfer of knowledge, skills, or competencies between HR (Hsu \& Fang, 2009).

Elements of $\mathrm{HC}$ can be classified into two, namely 1) knowledge, ability, and competence in important fields; and 2) individual attitudes, behavior and talents. The manifestation of $\mathrm{HC}$ can be in the form of HR capabilities 
in problem solving, the ability to be a leader, as well as professional expertise in certain fields (Mohammadi, Sherafati, \& Ismail, 2014). In the micro and macro scale, investment in HC is the main focus of intangible resource management. The investment aims to be able to increase the quantity and quality of human resources who have education, skills, and experience that are appropriate to the needs of the workforce. Investment is done by increasing the effectiveness and efficiency of the implementation of HR education and training (Jhingan, 2012).

\subsubsection{Relational Capital}

The basic concept of Relational Capital (RC) considers that a company cannot stand alone without connectivity with the external environment. Companies need to have a mutually beneficial relationship with other companies to be able to make their respective goals achieved. The relationship is then considered to be one of the company's important capital known as Relational Capital (RC) (Leaniz \& Bosque, 2013).

Relational Capital (RC) is defined as capital in the form of relationships, networks, or other forms of attachment between companies and external parties (Pouraghajan \& Ramezani, 2013). In addition to representing relationships with external parties, $\mathrm{RC}$ also relates to relationships that are formed within the company's internal scope (Pablos, 2003). That is, RC covers the entire relationship, both internally and externally, which is one of the company's basic capital to achieve its objectives.

Relational Capital (RC) can be divided into two main categories, namely the category of relationships between companies and service users or customers and the category of relationships between companies and stakeholders or investors. The first category, namely the relationship with customers makes $\mathrm{RC}$ as a means to expand the market in order to increase sales or revenue, while the second category, namely the relationship with stakeholders is more oriented to ensure the stability of financial capital needed as one of the basis for intellectual capital creation (Sharifi \& Bijani, 2014).

Relational capital is a dimension of intellectual capital that is reflected in three main forms, namely: 1) in the form of networks, cooperation, and associations in terms of knowledge distribution; 2) in the form of relationships with customers, business partners, and all stakeholders, both from internal and external companies; and 3) in the form of principles of trust, image and mutual commitment in maintaining good relations (Datta \& De, 2016).

\subsubsection{Structural Capital}

Structural capital (SC) is the dimension of IC which covers all assets other than HC. SC facilitates the storage and empowerment of knowledge. SC can be in the form of company databases, operational work systems and procedures, production processes, corporate strategies, and others (Pablos, 2003).

Structural capital (SC) can be divided into two, namely internal structure and external structure. The internal structure includes all intangible resources that remain in the company with or without HR. This structure can be in the form of daily work processes, databases and models of information flow, leadership style in the company, or work culture that applies in the company (Aramburu, Saenz, \& Blanco, 2015). External structures relate to all aspects that facilitate the relationship between the company and external parties. This structure can be in the form of company image, company competitiveness, customer satisfaction and loyalty, or other intangible assets (Aramburu et al., 2015). Structural capital (SC) has several indicators, including organizational culture, organizational structure, organizational learning, operational processes, and information systems.

\section{Research Methods}

The type of this research is a qualitative approach, namely the approach taken by explaining and analyzing phenomena or events. The qualitative approach has an inductive nature because the researcher will let all problems arise to be analyzed based on data and theory (Hamdi \& Bahrudin, 2014). Through a qualitative approach, researchers will examine the role of intellectual capital in overcoming the problems of slowing economic growth that occur in Indonesia.

Intellectual capital has three main dimensions, namely human capital, structural capital, and relational capital. Among these three dimensions, this study will examine specifically the role of the human capital dimension to overcome the slowdown in the Indonesian economy.

The data of this study are secondary data collected by researchers through documentation studies on literature in the form of data relating to human capital and Indonesia's economic growth, as well as the results of previous studies that have relevance to the topic of this research. The data obtained were then analyzed using qualitative methods in three stages, namely data reduction, data presentation, and verification withdrawal. 


\section{Discussion}

All economic activities, both in company and national level, cannot be run without the role of Human Capital (HC) (Hsu \& Fang, 2009). On a company scale, the intellectual aspect of HC is recognized as a source of innovation and the creation of superior competitiveness, as well as being a differentiator between one company and another (Theriou et al., 2009). In addition, HC is also the main foundation of the company in implementing operational aspects that cannot be done automatically by machines or computer equipment. Thus, the existence of $\mathrm{HC}$ is absolutely necessary to make the company or organization able to carry out all its economic activities in order to continue to survive and achieve its goals.

Human capital (HC) refers to all aspects possessed by HR, which have the potential to generate benefits, such as knowledge, abilities, and competencies in important fields, as well as individual attitudes, behaviors, and talents (Mohammadi et al., 2014). If in the context of a company, $\mathrm{HC}$ enable the company to compete and achieve its objectives, then in a larger context, namely the country, $\mathrm{HC}$ can be seen as one of the main factors in production activities that have a dominant influence in encouraging the increament of production. The higher the quality of $\mathrm{HC}$, the higher the quantity and quality of products. In addition, the production process will also be carried out more effectively and efficiently (Jihène, 2013).

At a higher level, $\mathrm{HC}$ can have a role as a decision maker and economic policy maker. In this case, the higher the intellectuality of $\mathrm{HC}$, the more appropriate policies are made to overcome various economic problems being faced. The quality of $\mathrm{HC}$ can be seen from a variety of individual abilities, such as the ability to overcome problems, become leaders, and the level of expertise in a particular field (Mohammadi et al., 2014). One indicator that can be used to determine the level of $\mathrm{HC}$ quality and its development is the Human Development Index (HDI) (Arabi \& Abdalla, 2013). The higher the HDI value, the higher the level of HC quality, which is identical to the stable economic growth of a country.

According to data compiled by the United Nations Development Program (UNDP) (2016), it is known that the value of Indonesian HDI in the period 2010-2015 did not increase much. If compared with HDI from developed countries which are also included in ASEAN countries and located close to Indonesia, namely Singapore, there will be a very striking difference in terms of the value of HDI and its annual increment.

Table 1. Comparison of Indonesian and Singapore HDI

\begin{tabular}{ccc}
\hline Year & Indonesia & Singapore \\
\hline 2000 & 0,604 & 0,820 \\
2010 & 0.662 & 0.911 \\
2011 & 0.669 & 0.917 \\
2012 & 0.677 & 0.920 \\
2013 & 0.682 & 0.922 \\
2014 & 0.686 & 0.924 \\
2015 & 0.689 & 0.925 \\
\hline
\end{tabular}

Source: UNDP (2016).

The data above shows that Indonesia's HDI is very low when compared to Singapore's. In addition, the annual increment of Indonesian HDI is very small and is still around 0.6 from 2000 to 2015. This is different from Singapore which showed a significant increase in HDI from 0.820 in 2000 to 0.925 in 2015.

The difference in HDI between Indonesia and Singapore shows that there are significant differences in HC quality, while the difference in HDI increment from year to year indicates a difference in HC development orientation. Singapore, which is able to increase HDI significantly from year to year, is a country that makes the human resources quality development as a top priority in the national development agenda, which makes Singapore become one of the developed countries that have very high HDI in the world. In contrast to Indonesia, which has a low HDI and does not experience a significant increase from year to year, shows the lack of efforts to emphasize the national development on $\mathrm{HC}$ quality aspects.

Indonesia's economic growth does have a relationship with 1) household consumption, social spending, and major events; 2) government consumption; 3) investment; and 4) exports and imports (Www.Kemenkeu.go.id, 2017). However, when problems occur in the form of slowing economic growth as they are today, more fundamental thinking is needed to overcome them, namely by prioritizing development priorities to encourage the improvement of $\mathrm{HC}$ quality owned by Indonesia. This can be done by increasing investment in $\mathrm{HC}$ in the 
form of building education and training facilities that have relevance to the needs of the workforce (Jhingan, 2012). In addition, investments can also be made through the construction of facilities and infrastructure that facilitate public health needs (Arabi \& Abdalla, 2013; Borojo \& Yushi, 2015). HC quality improvement will encourage the increasing role of $\mathrm{HC}$ as a production force as well as a crucial economic policy maker to overcome various economic problems that exist in Indonesia.

\section{Conclusions and Recommendations}

\subsection{Conclusions}

Based on the overall discussion of this study, the conclusions that can be drawn include: 1) intellectual capital has a fundamental role in overcoming the economic slowdown in Indonesia. One dimension of intellectual capital, namely human capital, can have a diverse role, both as a factor of production and as an economic policy maker, so that its existence and quality determine the success of the strategy formulation and its implementation to overcome the economic slowdown in Indonesia; and 2) the role of intellectual capital, especially human capital, can be realized if Indonesia changes its development paradigm to become more oriented towards the development of human resources quality.

\subsection{Theoretical Implications}

This research contributes theoretically through the provision of an analysis that links theories that have organizational scope, namely resource based theory (RBT) and intellectual capital theory, with the macro scope, that RBT can not only be applied in a small scope such as organizations or companies, but can also be applied in a larger scope such as in a country scale. Other contributions are in the form of an analysis of the relationship between RBT and four theories of economic growth, that are classical growth theory, Schumpter theory, Harrod Domar theory, and neo classical theory, namely in terms of human capital as the main factor that determines economic growth.

\subsection{Managerial Implications}

The Indonesian government needs to make changes in development orientation to not only focus on building business facilities, but rather on development that encourages the improvement of the quality of human resources, such as the construction of quality education and training facilities that are relevant to the needs of the workforce. In addition, the government also needs to increase the existence and ease of access to facilities and infrastructure that guarantee public health. These orientation will be able to accelerate the improvement of the quality of Indonesian human capital.

\subsection{Suggestions}

This research was conducted with qualitative methods based on data obtained from documentation studies on data related to human capital and economic growth. Therefore, further research is needed to improve the results of this study. Those advanced research can be done with quantitative methods and uses data on all dimensions of intellectual capital and all indicators of economic growth.

\section{References}

Abdulai, M. S., \& Kwon, Y. (2012). Intellectual Capital And Firm Performance: An Empirical Study Of Software Firms In West Africa. The African Journal Of Information Systems, 4(1), 1-30.

Ansari, S., Roodbari, A., Aboosaedi, L. R., \& Nassaji, H. (2016). Intellectual Capital as the Facilitating Infrastructure of Knowledge Creating and Sharing. International Journal of Economics, Commerce, and Management, $I V(6), 100-117$.

Arabi, K. A. M., \& Abdalla, S. Z. S. (2013). The Impact of Human Capital on Economic Growth: Empirical Evidence from Sudan. Research in World Economy, 4(2), 43-53.

Aramburu, N., Saenz, J., \& Blanco, C. E. (2015). Structural capital, innovation capability, and company performance in technology-based colombian firms. Cuadernos de Gestion, 15(1), 39-60. https://doi.org/10.5295/cdg.130427na

Berg, H. Van den. (2013). Growth theory after Keynes, part I: The unfortunate suppression of the Harrod-Domar model. The Journal of Philosophical Economics, VII(1), 1-23.

Bi.go.id, W. (2017). Laporan Tahunan Bank Indonesia. Retrieved from https://www.bi.go.id/id/publikasi/laporan-tahunan/perekonomian/Pages/LPI_2017.aspx

Borojo, D. G., \& Yushi, J. (2015). The Impact of Human Capital on Economic Growth in Ethiopia. Journal of Economics and Sustainable Development, 6(16), 109-119. 
Canizares, S. M., Munoz, M. A., \& Guzman, T. L. (2007). Organizational Culture And Intellectual Capital: A New Model. Capital, Journal Of Intellectual, 8(3), 409-430. https://doi.org/10.1108/14691930710774849

Cheng, M. Y., Lin, J. Y., Hsiao, T. Y., \& Lin, T. W. (2010). Invested resource, competitive intellectual capital, and corporate performance. Journal of Intellectual Capital, 11(4), 433-450. https://doi.org/10.1108/14691931011085623

Croitoru, A. (2012). The Theory of Economic Development: An Inquiry into Profits, Capital, Credit, Interest and the Business Cycle, translated from the German by Redvers Opie, New Brunswick (U.S.A) and London (U.K.): Transaction Publishers. Journal Of Comparative Research In Anthropology And Sociology, 3(2), 137-148.

Datta, S. K., \& De, T. (2016). Role of Relational Capital and Firm Performance: Analysis of a Cluster of Bell-metal Enterprises in a Rural Region in West Bengal, India. Journal of Entrepreneurship \& Organization Management, 6(1), 1-6.

Ewubare, D. B., \& Ogbuagu, A. R. (2015). Capital Accumulation and Economic Growth in Nigeria "Endogenous Growth Approach." IOSR Journal of Economics and Finance, 6(6), 49-64.

Hamdi, A. S., \& Bahrudin, E. (2014). Metode Penelitian Kuantitatif Aplikasi Dalam Pendidikan. Yogyakarta: Deepublish.

Havi, E. D. K., Enu, P., Osei-Gyimah, F., Attah-Obeng, P., \& Opoku, C. D. K. (2013). Macroeconomic Determinants Of Economic Growth In Ghana: Cointegration Approach. European Scientific Journal, 9(19), 156-175.

Hsu, Y. H., \& Fang, W. (2009). Intellectual Capital And New Product Development Performance: The Mediating Role Of Organizational Learning Capability. Technological Forecasting And Social Change, 76, 664-677. https://doi.org/10.1016/j.techfore.2008.03.012

Jhingan, M. L. (2012). Ekonomi Pembangunan dan Perencanaan. Jakarta: Rajawali Press.

Jihène, S. (2013). The Impact of Human Capital on Economic growth: Case of Tunisia, Morocco, Japan and South KoreaI. Proceedings Book of ICEFMO, 8-18.

Kira, A. R. (2013). The Factors Affecting Gross Domestic Product (GDP) in Developing Countries: The Case of Tanzania. European Journal of Business and Management, 5(4), 148-158.

Leaniz, P. M. G. de, \& Bosque, I. R. del. (2013). Intellectual capital and relational capital: The role of sustainability in developing corporate reputation. Intangible Capital, 9(1), 262-280.

Li, J., Pike, R., \& Haniffa, R. M. (2008). Intellectual Capital Disclosure and Corporate Governance Structure in UK Firms. Accounting and Business Research, 38(2), 1-19. https://doi.org/10.1080/00014788.2008.9663326

Makki, M. A. M., \& Lodhi, S. A. (2014). Impact of Corporate Governance on Intellectual Capital Efficiency and Financial Performance. Pakistan Journal of Commerce and Social Sciences, 8(2), 305-339.

Maramis, C. N. J. (2013). Analisis Pertumbuhan Ekonomi, Konsumsi, Investasi, dan Ekspor Neto di Indonesia dan Sulawesi Utara sebelum dan sesudah Krisis Finansial Global tahun 2008. Jurnal EMBA, 1(4), 1431-1443.

Masoud, N. (2014). A contribution to the theory of economic growth: Old and New. Journal of Economics and International Finance, 6(3), 47-61. https://doi.org/10.5897/JEIF2013.0518

Mohammadi, R., Sherafati, M., \& Ismail, M. N. Bin. (2014). Factors Affecting Intellectual Capital and Its Role in Financial Performance of Organization. Indian Journal of Science Res, 5(1), 314-320.

Olalla, M. F. (1999). The Resource-Based Theory and Human Resources. Journal of IAER, 5(1), 84-92.

Orens, R., Aerts, W., \& Lybaert, N. (2009). Intellectual capital disclosure, cost of finance and firm value. Management Decision, 47(10), 1536-1554. https://doi.org/10.1108/00251740911004673

Pablos, P. O. de. (2003). Intellectual capital reporting in Spain: a comparative view. Journal of Intellectual Capital, 4(1), 61-81. https://doi.org/10.1108/14691930310455397

Pouraghajan, A., \& Ramezani, A. M. (2013). Impact Of Intellectual Capital On Market Value And Firm's Financial Performance: Evidence From Tehran Stock Exchange. World of Sciences Journal, 1(12), 197-208.

Saepudin, T. (2013). Pertumbuhan Ekonomi Manusia dan Pertumbuhan Ekonomi antar Daerah di Indonesia. 
Semnas Fekon: Optimisme Ekonomi Indonesia.

Sharifi, H., \& Bijani, R. Z. (2014). The Impact of Intellectual Capital on the Financial Performance of Listed Companies in Tehran Stock Exchange. International Journal of Academic Research in Accounting, Finance and Management Sciences, 4(1), 119-127.

Solikhah, B., \& Subowo. (2016). An Empirical Study of the Driver Factors of the Intellectual Capital Disclosure. Rev. Integr. Bus. Econ. Res., 5(1), 229-240.

Theriou, N. G., Aggelidis, V., \& Theriou, G. N. (2009). A Theoretical Framework Contrasting the Resource-Based Perspective and Knowledge-Based View. Journal of European Research Studies, XII(3), 177-190.

UNDP. (2016). Human Development Report 2016 Human Development for Everyone. New York.

Wan, W. P., Hoskisson, R. E., Short, J. C., \& Yiu, D. W. (2011). Resource-Based Theory And Corporate Diversification: Accomplishments And Opportunities. Journal Of Management, 37(5), 1335-1368. https://doi.org/10.1177/0149206310391804

Www.Kemenkeu.go.id. (2017). 4 Hal ini Tingkat Pertumbuhan Ekonomi di 2018. Retrieved from https://www.kemenkeu.go.id/publikasi/berita/4-hal-ini-tingkatkan-pertumbuhan-ekonomi-di-2018/

\section{Copyrights}

Copyright for this article is retained by the author(s), with first publication rights granted to the journal.

This is an open-access article distributed under the terms and conditions of the Creative Commons Attribution license (http://creativecommons.org/licenses/by/4.0/). 